\title{
Identification of a developmental timer regulating the stability of embryonic cyclin $A$ and a new somatic A-type cyclin at gastrulation
}

\author{
John A. Howe, ${ }^{1,3}$ Mike Howell, ${ }^{2,3}$ Tim Hunt, $^{2}$ and John W. Newport ${ }^{1,4}$ \\ ${ }^{1}$ Department of Biology, University of California at San Diego, La Jolla, California 92093-0347 USA; ${ }^{2}$ Imperial Cancer \\ Research Fund (ICRF) Clare Hall Laboratories, South Mimms, Herts, EN6 3LD, UK
}

\begin{abstract}
We have identified a second Xenopus cyclin A, called cyclin A2. Cyclin A2 is a 46.6-kD protein that shows a greater homology to human cyclin A than to the previously identified Xenopus cyclin A1. It is present throughout embryonic development (up to stage 46 at least) and is found in adult tissues as well as in Xenopus tissue culture cell lines. In contrast, cyclin A1 is present in eggs and early embryos but cannot be detected in late embryos or in tissue culture cells. We have found that the maternally stored pools of mRNAs encoding both of these cyclin $A$ proteins are stable until the onset of gastrulation and then are degraded abruptly. At this time, new transcription replaces cyclin A2 mRNA. Interestingly, we have also observed a dramatic change in the stability of the cyclin A proteins at this time. Prior to the onset of gastrulation, cyclin A1 protein is stable during interphase of the cell cycle. At gastrulation, however, both A1 and A2 proteins turn over rapidly during interphase of the cell cycle. Together, these results indicate that developmental programs controlling cyclin A protein and mRNA stability are activated at gastrulation. We have shown that this program is independent of new transcription beginning at the mid-blastula transition. Furthermore, treatment of early stage embryos with cycloheximide demonstrates that activation of this degradative program is independent of cell division and translation. Collectively, our observations suggest that a previously uncharacterized timing mechanism activates new degradative pathways at the onset of gastrulation, which could play an essential role in releasing cells from maternal programming.
\end{abstract}

[Key Words: Cyclin A; mRNA; protein; stability; development; timer]

Received February 23, 1995; revised version accepted April 7, 1995.

Cyclins are essential components of a number of cell cycle-controlling kinases. It is believed that the complexes formed between cyclins and cyclin-dependent kinase (cdk) subunits are required for a number of important transition events in the somatic cell cycle. The archetypal members of the cdk family of kinases, Schizosaccharomyes pombe $\mathrm{Cdc}^{+}$and Saccharomyces cerevisiae $\mathrm{Cdc} 28$, have been demonstrated to be essential genes whose products are required both during S-phase and at the $G_{2}-M$ transition (Nurse et al. 1976; Nurse and Bissett 1981; Reed and Wittenberg 1990). In higher eukaryotes, these transitions seem to be accomplished by a number of distinct cdk subunits (Blow and Nurse 1990; Fang and Newport 1991). For example, the Xenopus cdc2 kinase complexed with cyclin B has been identified as maturation promoting factor (MPF) and is required for the $G_{2} / M$ transition, whereas cdk2 has been

\footnotetext{
${ }^{3}$ These authors contributed equally to this work. ${ }^{4}$ Corresponding author.
}

implicated in the initiation of S phase (Gautier et al. 1990; Fang and Newport 1991; Dulic et al. 1992). Although the precise function of the cyclin subunit within the cyclin-cdk complex has not been fully elucidated, it is probable that it contributes to the recognition of the complex by regulatory kinases and phosphatases (R. Poon, M. Howell, K. Yamashita, and T. Hunt, in prep.) and to the substrate recognition of the complex either by providing additional binding sites and/or by directing the complex to a particular subcellular location (Pines and Hunter 1991).

Although cyclins were first identified in the early embryos of sea urchins and clams, they have since been identified in a wide range of organisms (for review, see Hunt 1991). The first cyclins identified were considered initially to be mitotic cyclins based on their ability to drive cell extracts into M phase (Minshull et al. 1989; Murray and Kirschner 1989), their specific proteolysis at the metaphase-anaphase transition (Murray et al. 1989; Glotzer et al. 1991) and, for the B-type cyclins, by their 
Cyclin A stability during embryogenesis

presence in purified preparations of MPF (Gautier et al. 1990). It has subsequently been demonstrated that at least one of these mitotic cyclins, cyclin A, plays some role during S phase (Girard et al. 1991; Pagano et al. 1992). The family of cyclins has now broadened, along with the possible phases of the cell cycle in which they act (Koff et al. 1991, Lew et al. 1991; Matshushime et al. 1991; Xiong et al. 1991; Ohtsubo and Roberts 1993; Sherr 1993). For example, the pattern of expression of D-type cyclins has suggested a $G_{1}$ role (Baldin et al. 1993), whereas cyclin $E$ has been proposed to operate at the $\mathrm{G}_{1} / \mathrm{S}$ transition (Dulic et al. 1992).

There have been numerous studies on the functions and activities of cyclins and cdks during Xenopus oocyte maturation and in in vitro extracts of either activated or cytostatic factor (CSF)-arrested egg extracts. However, little is known about the roles of these important cell cycle regulators at later points of Xenopus embryogenesis. The first 12 cell cycles of Xenopus embryogenesis are rapid synchronous cleavage events $\mid \sim 25 \mathrm{~min}$ per cell cycle), with each cell cycle consisting of a complete round of DNA synthesis followed immediately by mitosis (Newport and Kirschner 1984). After the twelfth cell cycle, division becomes asynchronous and the length of the cell cycle increases gradually. At this time also, the rate of zygotic transcription increases $\sim 200$-fold, cell motility is initiated, and the synthesis of new proteins and activities not present in the unfertilized egg begins (Bachvarova and Davidson 1966; Newport and Kirschner 1982a,b). The timing of this developmental switch, termed the mid-blastula transition (MBT), is apparently independent of new transcription, elapsed time since fertilization, or "counting" of the number of cell divisions. Instead, onset of the MBT seems to be determined by the ratio of some cytoplasmic activity to the DNA content of the embryo (Newport and Kirschner 1982b; Kimelman et al. 1987). It has been suggested recently that the increase in transcription at the MBT might be attributable to the titration of inhibitory chromatin-associated proteins (Prioleau et al. 1994).

Although zygotic transcription begins at the MBT, it is not until the beginning of gastrulation that new mRNAs become limiting for cell cycle progression (Newport and Dasso 1989; S. Nichols and J. Newport, in prep.). This observation suggests that the maternal programs that regulate the cell cycle before gastrulation are replaced by zygotic programs at the onset of gastrulation. To study the transition between the embryonic and somatic cell cycles we undertook a systematic study of cyclin mRNAs and proteins during early Xenopus development. As a result of this analysis we have identified a second cyclin A, cyclin A2, which is expressed throughout development up to stage 46 and is found in Xenopus tissues and cultured Xenopus cell lines. In contrast, cyclin $\mathrm{Al}$ protein and $\mathrm{mRNA}$ disappear during gastrulation and are not found in tissue culture cells. A rigorous analysis of factors affecting the developmentally programmed turnover of cyclin A mRNA and protein has revealed a novel timing mechanism that activates degradation pathways at the onset of gastrulation.

\section{Results}

Cloning of a second Xenopus cyclin $A$

We considered it likely that there was a second Xenopus A-type cyclin for two reasons. First, we could not detect either RNA or protein corresponding to the previously identified cyclin Al in Xenopus tissue culture cell lines. Second, alignment of all cyclin A protein sequences available suggested that the Xenopus cyclin Al showed less homology to the cyclin A sequences from human and cow than might be expected given their relatively recent evolutionary divergence (Fig. 1A). In particular, the human, hamster, and cow cyclin A protein sequences shared a number of common sequence motifs not found in the Xenopus cyclin Al protein. Additionally, a partial cyclin A cDNA obtained from a porcine testis library showed greater similarity to Xenopus A1 than to cow cyclin A (C.F. Hawkins, pers. comm.). These observations suggested to us that there might be a second "somatic" cyclin A in Xenopus, distinct from the identified Xenopus cyclin A1. To pursue this possibility we used the human cyclin A cDNA to probe a Xenopus oocyte cDNA library at relatively low stringency and purified a number of positive clones (see Materials and methods). The longest clone containing both an initiation and termination codon is shown in full in Figure 1B and was used for all subsequent work. A second, incomplete clone showed a number of minor sequence differences $16.5 \%$ difference over its length; amino acid differences indicated above the sequence) probably reflecting the tetraploid origins of Xenopus, as has been observed for a number of other cDNAs (Jeffreys et al. 1980; Westley et al. 1981).

The predicted cyclin A2 protein is 416 amino acids long with a calculated molecular mass of $46.6 \mathrm{kD}$. The predicted amino acid sequence shows a number of characteristic cyclin motifs, namely the cyclin box (amino acid residues 162-336), thought to be required for cdk binding and/or substrate recognition and containing the most highly conserved residues between different cyclins. Cyclin A2 also contains a destruction box /sequence underlined in Fig. 1B/ that has been shown to be necessary for the specific proteolysis of cyclin Al protein (Stewart et al. 1994). Overall, cyclin A2 shows greater similarity and homology to human cyclin A than to $\mathrm{Xe}$ nopus cyclin Al $143.9 \%$ similarity to Xenopus cyclin Al and $59.3 \%$ similarity to human cyclin A). Within the cyclin box, Xenopus cyclin A2 shares $70 \%$ identity with Xenopus cyclin A1 and $84.6 \%$ identity with human cyclin A. As with other mitotic cyclins, the amino acid sequences upstream of the cyclin box are the least well conserved and show the greatest variability between cyclins.

Cyclin A2 is expressed in both eggs and tissue culture cells

On Northern blots cyclin A2 mRNA was detected in testis, XTC and WAK cells, eggs, and intestinal tissue cells (Fig. 2A; data not shown). Cyclin Al mRNA was 
B

A

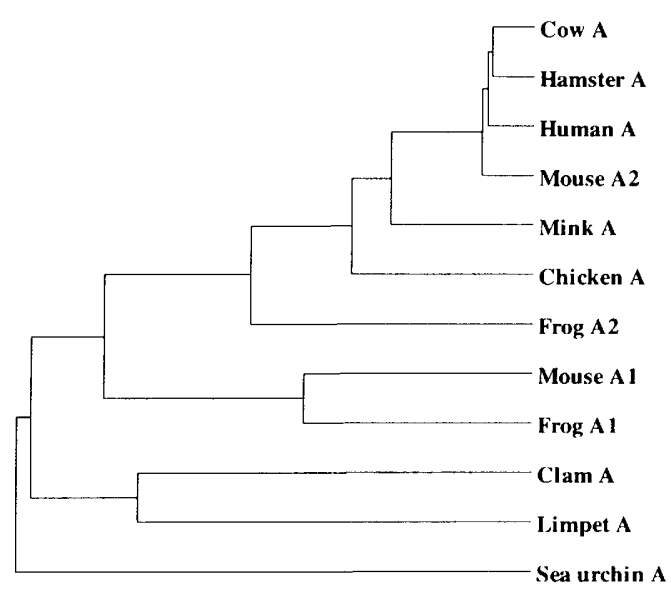

Figure 1. $(A)$ Cyclin A protein sequences from the conserved MRAIL sequence of the cyclin box to the carboxyl terminus (available in the GenBank data base) were aligned with the Intelligenetics Geneworks (Mountain View, CA) protein alignment module. Evolutionary relationships between sequences are displayed as a tree plot using the UPGMA method. $|B|$ The complete nucleic acid sequence and conceptual translation of the cyclin A2 mRNA. Features of interest noted in the text are highlighted: the destruction box (underlined), the cyclin box (bold face), the 5' UTR (nucleotides 1-257), the 3' UTR (nucleotides 1502-1688). Another cyclin A2 clone displaying minor amino acid differences is also shown; only amino acids differing from the sequence of the full-length clone are indicated (above the predicted amino acid sequence of the full-length sequence). The nucleic acid sequence used to isolate the full length $5^{\prime}$ UTR is indicated (nucleic acid sequence underlined with arrow).

identified in oocytes and eggs, and interestingly it also appears to be present in testis [a very similar situation pertains in mice (see Discussion)]. To characterize the cyclin A2 protein, both mono- and polyspecific antisera were prepared against bacterially expressed A2 protein. Consistent with our expectation that cyclin A2 represented a somatic form of cyclin A, we found that both antisera detected cyclin A2 in WAK and XTC Xenopus cell lines by Western blotting (Fig. 4B, below; data not shown). In contrast to tissue culture cells, both cyclin $\mathrm{Al}$ and A2 are present in eggs. Specifically, when cell-free extracts made from unfertilized eggs arrested in mitosis (CSF) were labeled with $\left[{ }^{35}\right.$ S $]$ methionine, small amounts of labeled cyclin $\mathrm{Al}$ and $\mathrm{A} 2$ could be detected following immunoprecipitation (Fig. 2B). However, following activation of these extracts by addition of $\mathrm{Ca}^{2+}$ both cyclins were rapidly synthesized and accumulated. In such $\mathrm{Ca}^{2+}$-treated extracts and in early stages of embryonic development (although not in tissue culture cells), cyclin A2 protein appeared as a doublet. This is probably the result of a phosphorylation event as the doublet was reduced to one band when anti-cyclin A2 immunoprecipitates were incubated with acid phosphatases /data not shown|.

\section{CDK binding to cyclin $A 1$ and $A 2$ during development}

Cyclin $\mathrm{A}$ is unique among the cyclin family because in somatic cells it complexes with both cdk2 and cdc2 (Tsai et al. 1991; Desai et al. 1992). This dual association is consistent with experimental evidence suggesting that cyclin A is essential for both DNA replication and the onset of mitosis. In contrast, it has been shown that cyclin Al associates exclusively with cdc2 in eggs, although it can bind both cdc2 and cdk2 in vitro (Minshull et al. 1990; Paris et al. 1991; Kobayashi et al. 1992; Gabrielli et al. 1992; Kobayashi et al. 1992). As such, it was of interest to determine how cyclin A2 distributed itself between these two kinases in eggs. To do this we used cyclin A2 antibodies to immunoprecipitate complexes from eggs at different embryonic stages. The amount of cdc2 and cdk2 kinase associated with these cyclin A2 complexes was then determined by Western blotting usthese experiments (Fig. 3) demonstrated clearly that cyclin $\mathrm{A} 2$, unlike cyclin $\mathrm{A} 1$, is associated with both cdc2 and cdk2 until at least stage 17.

It is interesting to note that after the MBT (Fig. 3, stages 9 and 10), the cdc2 associated with cyclin A2 miing anti-cdc2 and anti-cdk2 antibodies. The results from 
A

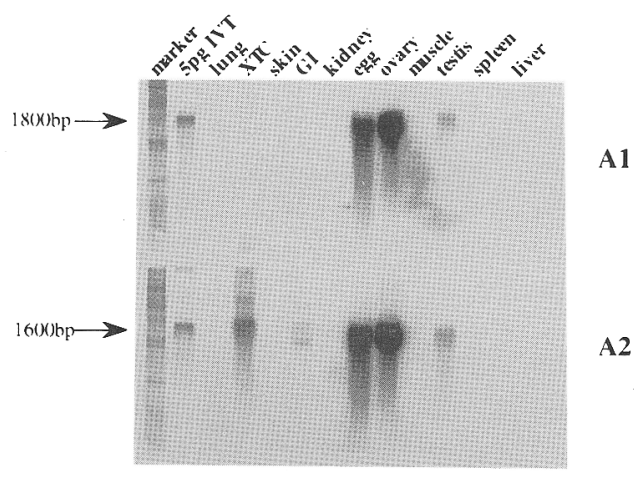

B

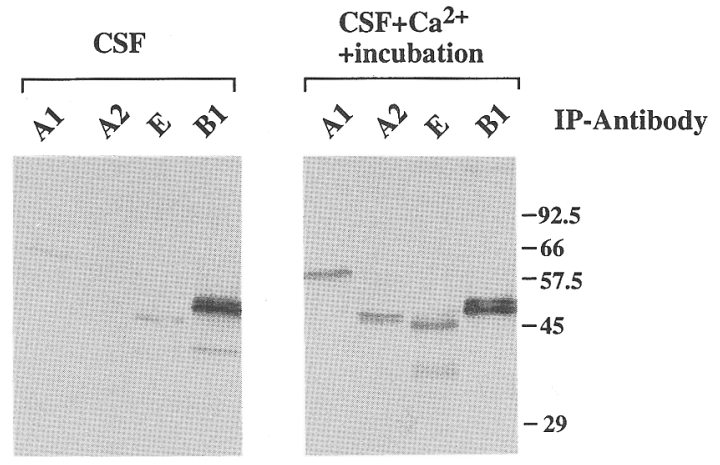

Figure 2. (A) A Northern blot of cyclin $\mathrm{A} 1$ and $\mathrm{A} 2$ mRNA present in total RNA from a number of Xenopus tissues. Total RNA $(25 \mu \mathrm{g})$ was probed with a random-primed probe corresponding to either full-length cyclin A1 (top) or A2 (bottom). A positive control mRNA ( $5 \mathrm{pg}$ ) of in vitro-transcribed full-length cyclin A was used in each blot (IVT). Tissues are indicated at the top: (XTC) Xenopus tissue culture cell line; $\mid \mathrm{GI})$ gastrointestinal tract. Markers are ${ }^{35} \mathrm{~S}$-labeled $\lambda$ BstEII DNA. $(B)$ Cyclin A2 is present in $\mathrm{Ca}^{2+}$-treated CSF extracts. CSF extracts were incubated with either $\left[{ }^{35} \mathrm{~S}\right]$ methionine only $(\mathrm{CSF})$, or $\left[{ }^{35} \mathrm{~S} \mid\right.$ methionine and $0.4 \mathrm{mM}$ (final concentration) of $\mathrm{Ca}^{2+}\left(\mathrm{CSF}+\mathrm{Ca}^{2+}\right)$ at $23^{\circ} \mathrm{C}$. After $2 \mathrm{hr}$ of incubation, extracts were immunoprecipitated with the specific rabbit antisera indicated at the top. Molecular mass markers are indicated at the right (in $\mathrm{kD}$ ).

grated as three separated bands, and at stage 17 , as only the top two bands of this triplet. Previous studies have shown that cdc2 migrates differentially on SDS-polyacrylamide gels as a result of the state of phosphorylation of two negative regulatory sites at Thr-14 and Tyr15 (Solomon et al. 1992). The slowest migrating band of the cdc2 triplet is known to be phosphorylated at both residues, Thr-14 and Tyr-15; the middle band of the triplet results from phosphorylation at either one of these residues; and the fastest migrating band of the triplet is not phosphorylated at either site. Our results suggest that the first detectable negative regulation (by phosphorylation of Thr-14 and Tyr-15) of cdc2 associated with cyclin A2 occurs after the MBT. This is in agreement with previous published results, showing that the feed- back controls that negatively regulate cdc2 by phosphorylation during DNA replication are first activated after the MBT (Dasso and Newport 1990).

\section{Developmental expression of cyclin $A 1$ and $A 2$ protein}

Because both cyclins A1 and A2 were present in eggs and only cyclin A2 was present in tissue culture cells, we examined the fates of these proteins during embryogenesis. To do this we collected eggs at different developmental stages and then used Western blots to determine the concentration of both cyclins $\mathrm{Al}$ and $\mathrm{A} 2$ present at these times. Following fertilization, cyclin A accumulated rapidly and was abundant during the rapid cell divisions that precede the MBT (Fig. 4A). The apparent stability of cyclin Al during this period should not be interpreted as indicating that cyclin Al is stable at mitosis during this time of development. Rather, it occurs because the cell cycles of different eggs within our sample are not tightly synchronized. As such, some eggs are in interphase and accumulating cyclin A while others are in mitosis and degrading cyclin Al (Minshull et al. 1990). The steady-state amount of cyclin Al shown in Figure $4 \mathrm{~A}$ represents an average of these synthetic and degradative states. Following the MBT, cyclin Al levels remained high during the next two to three elongated cell divisions. However, once these division cycles are completed cyclin Al protein levels declined rapidly during a 3 -hr period between stages 10 and 11 .

Cyclin A2 protein was detected throughout embryogenesis, although during the early cleavage cycles it was present in very low amounts (Fig. 4B,C). At, or soon after, the MBT (stage $81 / 2$ ), the levels of cyclin A2 increased until the beginning of gastrulation (stages 10-101/4) after which a relatively constant level was detected. This increase in cyclin A2 protein levels may represent some form of translational control, as it does not correspond with an increase in the level of mRNA (Fig. 5B). However, it does coincide with the start of zygotic transcription (see below), and although we have not observed any changes in the size of the mRNA or length of the $5^{\prime}$ untranslated region (UTR) at different stages of development, the formal possibility remains that zygotic cyclin A2 mRNA differs from maternal cyclin A2 mRNA in some subtle way so as to allow for an increased rate of

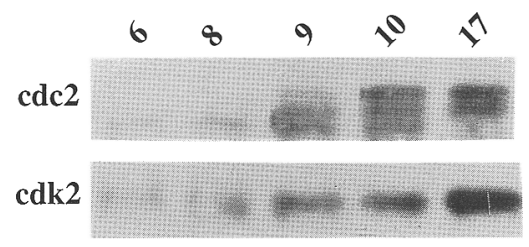

Figure 3. Association of cyclin $\mathrm{A} 2$ with cdc2 and cdk2 during early development. Cyclin A2 protein complexes were immunoprecipitated from extracts of staged embryos (stage indicated at top) using anti-peptide cyclin A2 antibody. After separation by SDS-PAGE the precipitates were immunoblotted with antipeptide cdc2 or anti-peptide cdk2 antibodies. 


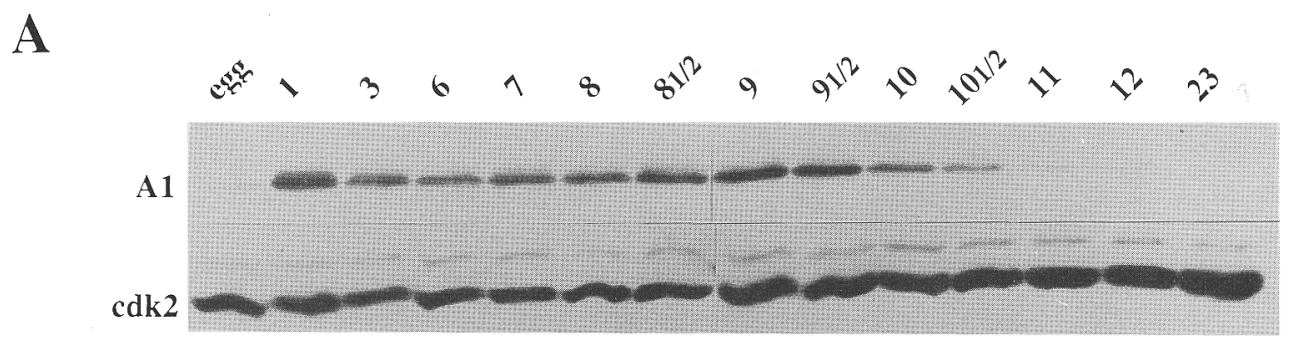

Figure 4. (A) Cyclin $\mathrm{A} 1$ and cdk2 protein levels during embryonic development. Cytosolic extracts of eggs or embryos (stages indicated above each lanel were subjected to SDS-PAGE and immunoblotted with antibodies that recognized cyclin A1 (sheep anti-A1) or a carboxy-terminal peptide of cdk2. $(B)$ Developmental expression of $c y-$ clin A2 and cdc2 protein. Total extracts were made from embryos (stages indicated) and from stage VI oocytes, eggs and WAK cells (a Xenopus kidney cell line). Blots were probed with either rabbit anti-A2 antiserum or anti-cdc2 monoclonal 3El. (C) Detection of cyclins $\mathrm{Al}$ and $\mathrm{A} 2$ during early development. p13 $3^{\text {Sucl }}$ affinity beads were used to isolate cyclin-cdk complexes from cytosolic extracts of embryos collected at the indicated stages. The proteins precipitated on the p13 $3^{\text {Sucl }}$ beads were separated by SDS-PAGE and immunoblotted with anti-peptide cyclin A2 and sheep anti-Al antibodies. Overexposure of this blot revealed cyclin A2 bands at stages 6 and 8 .

translation. The changes in the level of both $\mathrm{Al}$ and $\mathrm{A} 2$ protein at different developmental periods appear in sharp contrast to the pattern of expression of cdc2 and cdk2 over the same time course (Fig. 4A,B). The levels of these proteins changed little, if any, during the developmental periods examined.

\section{Cyclin $A 1$ and $A 2$ mRNA levels are developmentally regulated}

The pattern of expression of the A-type cyclins described above suggested that they were developmentally regulated. To explore the possible mechanisms of this control, we used Northern analysis of total RNA isolated from staged embryos to determine the fate of the cyclin messages during embryogenesis. These studies showed that cyclin A1 and A2 messages were present in nearly equivalent quantities in stage 6 oocytes (data not shown|. Following fertilization, cyclin Al mRNA levels remained constant during the rapid cleavage stages /Fig. $5 \mathrm{~A}, \mathrm{Cl}$ and the two or three slower divisions following the MBT. However, following these initial divisions, cyclin A1 mRNA began to decline after stage $91 / 2$ and was undetectable by stage 11. Cyclin A2 mRNA was also stable during the early cleavage stages (Fig. $5 \mathrm{~B}, \mathrm{C}$ ) but could be detected, at a lower steady-state concentration,
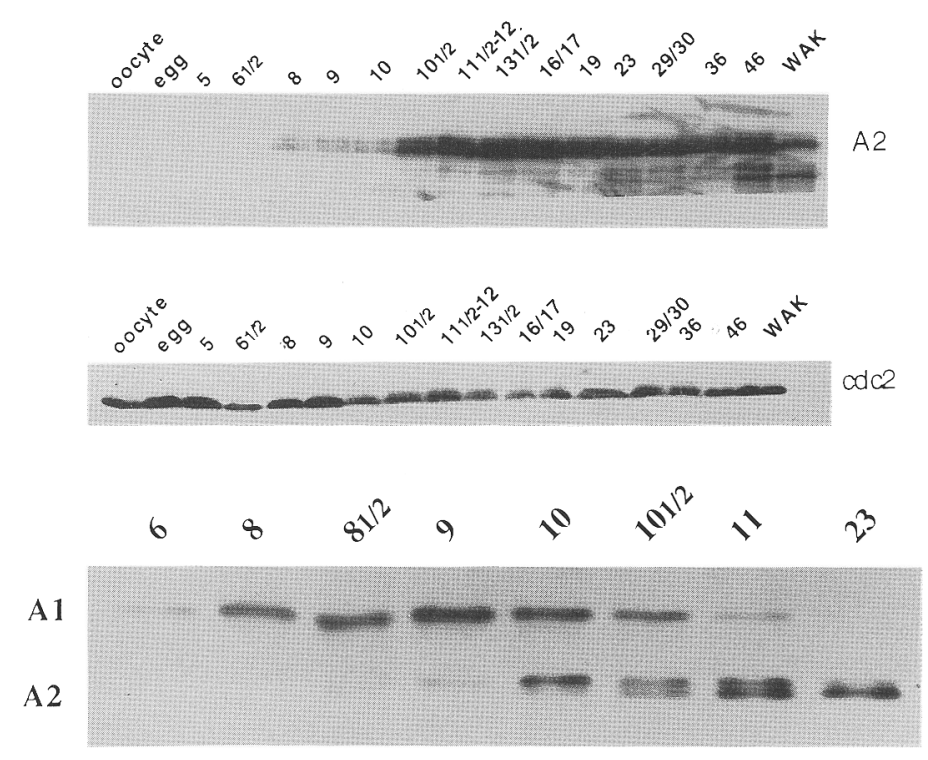

at time points after stage 11 when cyclin Al mRNA was not observed.

These results show that cyclin Al mRNA becomes unstable between stages $91 / 2$ and 10 . As such, these observations indicate that during this time a degradative pathway is activated that results in the turnover of cyclin Al maternal mRNA. We also observed a reduction in the levels of cyclin A2 mRNA by stage 11 and suspected that the same degradative pathway responsible for turnover of cyclin Al mRNA might also degrade the maternal pool of cyclin A2 message at this time. The observed persistence of A2 mRNA beyond stage 10 would be attributable to new zygotic transcription of cyclin A2 mRNA. To determine whether this is the case, we have examined the regulation of cyclin A1 and A2 mRNA levels during development under conditions in which zygotic transcription is reduced. Specifically, when fertilized eggs are incubated with the ribonucleotide reductase inhibitor hydroxyurea (HU), they divide normally up until the MBT (Newport and Dasso 1989). However, because of depletion of substrates for DNA synthesis at this point, the cells arrest in $\mathrm{S}$ phase of the twelfth cell cycle and further cell division does not occur. Therefore, embryos grown in the presence of $\mathrm{HU}$ do not undergo the two or three additional cell divisions that normally occur between the MBT and stage 10 . 
A

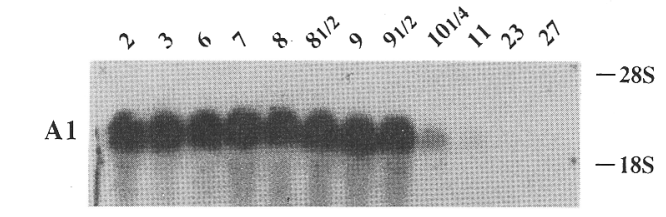

B

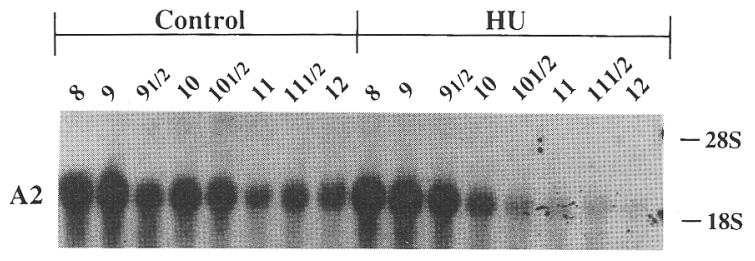

C

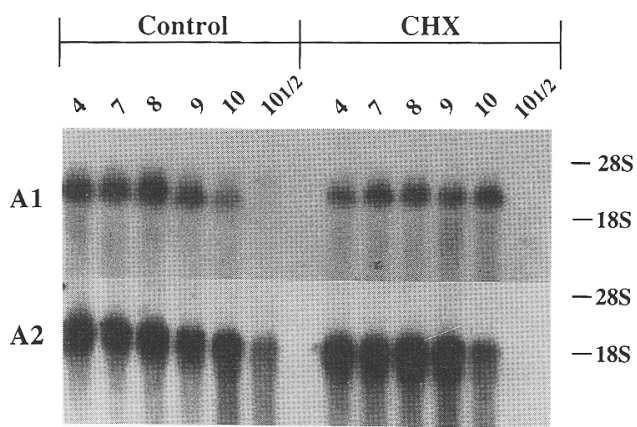

Figure 5. Northern analysis of cyclin $\mathrm{Al}$ and $\mathrm{A} 2$ RNAs during early development. $(A-C)$ Fifteen micrograms of total RNA, isolated from staged embryos (stages indicated above panels), were separated by agarose gel electrophoresis and Northern blotted with random-primed ${ }^{32} \mathrm{P}$-labeled cyclin A1 or cyclin A2 DNA fragments. Positions of $28 \mathrm{~S}$ and $18 \mathrm{~S}$ rRNAs are indicated at right. (A) Cyclin Al RNA at various developmental stages. (B) Cyclin A2 RNAs in control and HU-treated embryos. HU was added at stage $3 .(C)$ Cyclin $\mathrm{A} 1$ and $\mathrm{A} 2$ RNAs from control and $\mathrm{CHX}$-treated embryos. CHX was added at stage 4 .

These arrested embryos contain about six-fold fewer cells and nuclei than untreated embryos at stage 10 and synthesize six-fold less mRNA (Landstrom et al. 1975; J. Newport, unpubl.).

By using HU limit embryonic transcription, we have investigated whether the reduced level of cyclin A2 mRNA after stage 10 is independent of zygotic transcription. As shown in Figure $5 B$, in embryos arrested at the MBT with $\mathrm{HU}$, maternal cyclin A2 mRNA remained stable until a time equivalent to stage $91 / 2$. However, cyclin A2 mRNA rapidly became unstable beyond this time period and was almost completely degraded by stage 11 . The kinetics of degradation of A2 mRNA under these conditions were nearly identical to the degradative patterns observed for cyclin Al mRNA in control embryos (Fig. 5A). These experiments suggest several conclusions. First, the complete degradation of cyclin A2 mRNA in these transcriptionally limited embryos sup- ports the conclusion that the A2 mRNA levels after stage 10 are the result of new zygotic A2 mRNA transcription. Second, the temporal correlation of $\mathrm{Al}$ and $\mathrm{A} 2$ degradation at stage 10 suggests that destabilization of these two maternal mRNAs is regulated by a common degradative pathway that is activated at, or just before, stage 10. Third, the observation that this degradative pathway is activated at the correct time in embryos that have stopped dividing suggests that cell division beyond the MBT is not an essential element in regulating the activation of this mRNA degradative pathway.

To pursue further the relationship between cell division and activation of cyclin A mRNA degradation we have arrested cell division prior to the MBT and then examined how this affects the timing of cyclin A mRNA degradation. When fertilized eggs are treated with the protein synthesis inhibitor cycloheximide (CHX), accumulation of the mitotic cyclins A, B1, and B2 is blocked and cells arrest in $S$ phase of the embryonic cell cycle. Using CHX, we have blocked cell division prior to the MBT and asked how this affects the time at which cyclin $\mathrm{Al}$ and A2 mRNAs are degraded. To do this, eggs were fertilized and allowed to divide until the 8- to 16-cell stage, and $\mathrm{CHX}$ was added. Following addition of $\mathrm{CHX}$, the eggs divided once or twice more and then arrested (32- to 64-cell stage). Following arrest, the cyclin A1 and A2 mRNA levels present in these embryos were determined at different times by Northern blotting (Fig. 5C). The results from these experiments showed clearly that cyclin Al and A2 mRNAs were stable during the time period up to stage 10 . However, after this period, degradation of both mRNAs occurred very rapidly such that both mRNAs were completely degraded by a time period equivalent to stage $101 / 2$. The kinetics of degradation of these two messages were nearly identical to the rate of cyclin Al mRNA degradation in control dividing eggs. These results strongly suggest that activation of the maternal cyclin A mRNA degradation pathway is independent of cell division. Moreover, because CHX-arrested embryos contain very few nuclei relative to stage $10 \mathrm{em}$ bryos (64 vs. $16,000-32,000)$ this result provides further evidence that activation of the maternal cyclin A mRNA degradation pathway is independent of new transcription. These results also strongly suggest that activation of this degradative pathway is independent of continued protein synthesis. Taken together, our results indicate that degradation of both maternal cyclin $\mathrm{Al}$ and $\mathrm{A} 2 \mathrm{mR}$ NAs is regulated by a pathway that becomes active for the first time in development at stage 10. Because this degradative pathway is activated at a time when the embryo is showing the first visible signs of gastrulation, we have termed this period the early gastrulation transition (EGT). Together, the results presented above strongly suggest that the developmental timer that controls when cyclin Al and A2 maternal mRNA is degraded is independent itself of the cell cycle, new transcription, ongoing protein synthesis, DNA replication, and the nuclear to cytoplasmic ratio present in an embryo. We have noted and characterized a number of other changes in embryonic programming which also appear to be con- 
trolled by this EGT timer, and these will be described elsewhere (S. Nichols and J. Newport, in prep.).

The stability of cyclin $A 1$ and $A 2$ proteins is dependent on the stage of development

The activation of a cyclin A mRNA degradative pathway at the EGT suggested that other important regulatory systems might be activated at this time as part of a larger developmental program designed to allow a highly regulated somatic cell cycle to emerge from the simple biphasic, maternally programmed, embryonic cell cycle. In particular, we were interested in determining whether cyclin A proteins, like cyclin A mRNAs, were degraded at the EGT by a mechanism that was independent of cell division, translation, and new mRNA synthesis. To address this question we treated embryos with $\mathrm{CHX}$ shortly after fertilization. Under these conditions, eggs arrest in S phase of the cell cycle because they do not accumulate sufficient quantities of cyclins A and B to enter mitosis. Although the cyclin levels in these eggs are lower than required to enter mitosis, they are adequate for measuring changes in the dynamic stability of these proteins at different times in development.

To determine the rate of cyclin $\mathrm{Al}$ protein turnover before the EGT, embryos were treated with $\mathrm{CHX}$ at stage 3-4 (2 hr after fertilization) and cyclin A1 protein levels were monitored by $\mathrm{p} 3^{\mathrm{Suc} 1}$ depletion and Western analysis (Fig. 6). Cyclin Al was readily detected in CHXtreated embryos and was stable in lysates of embryos collected at the equivalent of stages 8,9 , and 91/2. However, by the time control embryos had reached stage $101 / 4$, the level of cyclin Al protein in CHX-treated embryos was just above the detectable level, and at stage 11 cyclin Al could not be detected (Fig. 6). The time course of destruction of cyclin Al coincided almost exactly with the onset of the EGT. In contrast, cyclin B2 and cdk2 levels did not vary significantly during the time course of the experiment, and these proteins were readily

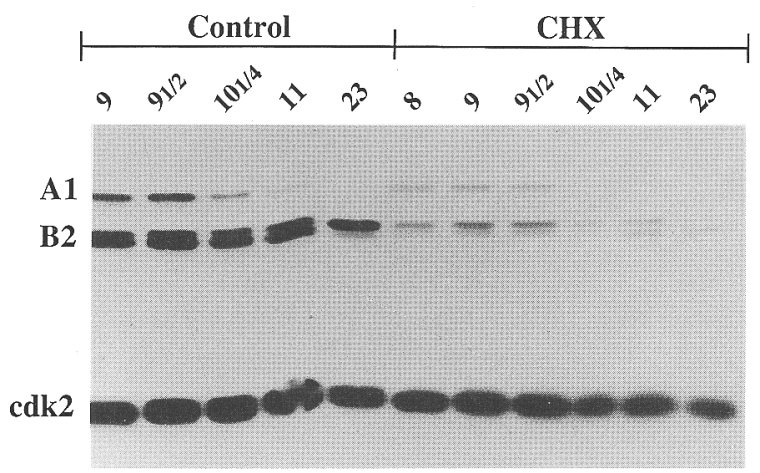

Figure 6. Cyclin turnover in control and CHX-treated embryos. p13 ${ }^{\text {Sucl }}$ affinity bead precipitates, prepared from control or CHX-treated embryos (stages indicated at top) were immunoblotted with antibodies against cyclin $\mathrm{Al}$ (sheep anti-A1), cyclin B2 (rabbit anti-B2), and cdk2 (anti-peptide). CHX- was added at stage 3 .
A

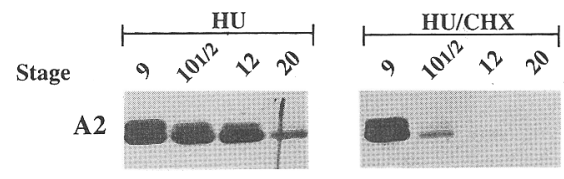

B

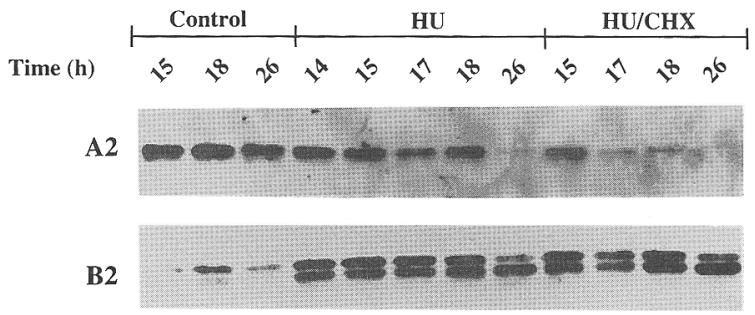

Figure 7. $(A)$ Cyclin A2 protein stability at the EGT. Embryos were treated with $\mathrm{HU}$ or with and then $\mathrm{CHX}(\mathrm{HU} / \mathrm{CHX})$ as described in the text. Embryos were collected at the time that untreated embryos reached the stage indicated above each lane. p $13^{\text {Sucl }}$ precipitates, from extracts of the treated embryos, were separated by SDS-PAGE and immunoblotted with anti-peptide cyclin A2 antibody. (B) Measurement of the stability of cyclin $\mathrm{A} 2$ and B2 proteins after the EGT. Embryos were either not treated (control), treated with $\mathrm{HU}$, or treated with $\mathrm{HU}$, and then $\mathrm{CHX}$ ( $\mathrm{HU} / \mathrm{CHX})$ as detailed in the text. Embryos were collected at the indicated times after fertilization. For analysis of cyclin $\mathrm{A} 2$ and cyclin B2 proteins, cyclin-cdk complexes were concentrated on p13 $3^{\text {Sucl }}$ affinity beads, separated by SDS-PAGE, and immunoblotted with anti-peptide cyclin A2 or cyclin B2 (rabbit anti-B2) antibodies.

detected until at least stage 23 . These results suggest that cyclin Al protein is intrinsically stable, except at mitosis, during early development until the EGT when it becomes dynamic and turns over rapidly.

Because our antibodies could not reproducibly detect the low levels of cyclin A2 present when eggs were treated with $\mathrm{CHX}$, we could not use this drug alone to determine whether $\mathrm{A} 2$ protein, like Al protein, became dynamic at the EGT. Instead, to analyze the turnover of cyclin A2 protein during the EGT, we arrested eggs at the MBT with HU to allow detectable quantities of cyclin A2 to accumulate. The turnover rate of this accumulated pool of cyclin A2 protein was then analyzed by incubating arrested embryos with CHX just before the onset of gastrulation. Specifically, embryos that had been arrested at the MBT with HU were incubated an additional $2.5 \mathrm{hr}$ longer to allow cyclin A2 to accumulate. At this time point, which was equivalent to late stage 9 in untreated embryos, $\mathrm{CHX}$ was added to prevent additional cyclin A2 protein synthesis. At the time of cycloheximide addition (stage 9), significant amounts of cyclin A2 protein were detected in HU-treated embryos (Fig. 7A). However, this pool of cyclin A2 protein was degraded almost completely after $\mathrm{CHX}$ treatment for $2.5 \mathrm{hr}$ (equivalent to stage $10^{1 / 2}$ ) and cyclin A2 could not be detected at later time points. In contrast, significant quantities of cyclin A2 were detected in eggs treated with $\mathrm{HU}$ alone at 
time points equivalent to stages $10 \frac{1}{2}$ and 12 . This experiment demonstrates clearly that cyclin A2 turns over rapidly at the EGT with a half-life that is significantly $<2.5 \mathrm{hr}$.

To measure cyclin A2 protein dynamics after the EGT, stage 9 embryos ( $8 \mathrm{hr}$ after fertilization) were transferred to buffer containing $30 \mathrm{~mm} \mathrm{HU}$ and then incubated an additional $6 \mathrm{hr}$ (14 hr after fertilization). Under these conditions, DNA replication is blocked and embryos remain arrested in S phase of the cell cycle. At $14 \mathrm{hr}$ following fertilization, new protein synthesis was blocked in half of these interphase-arrested embryos by addition of CHX. After a further incubation both CHX-treated and untreated embryos were collected and analyzed for cyclin A2 and cyclin B2 proteins. The results from these experiments (Fig. 7B) showed that existing cyclin A2 protein was degraded almost completely within $3 \mathrm{hr}$ after addition of $\mathrm{CHX}$ to interphase-arrested eggs. As a control to demonstrate that this rapid turnover rate was specific to cyclin A, we determined that cyclin B2 levels in the same eggs did not decline over a much longer period of time, 10-12 hr (Fig. 7B). These results indicate that following the EGT cyclin A2, like cyclin A1, becomes dynamic in interphase of the cell cycle and has a half-life of between 1 and $1.5 \mathrm{hr}$. As such, the steady-state level of cyclin A2 protein in an interphase cell following the EGT will be determined both by its rate of synthesis and its rate of degradation. Importantly, the developmental timer that activates degradation of cyclin $\mathrm{A}$ proteins at the EGT, like the timer regulating activation of cyclin mRNA degradation, appears to be independent of cell division, new transcription, ongoing protein synthesis, and the nuclear to cytoplasmic ratio in embryos.

\section{Expansion of the cell cycle after the $M B T$}

In eggs, the early cleavage cell cycles following fertilization are equally divided between $S$ and $M$ phases and lack measurable $G_{1}$ and $G_{2}$ phases. Following the MBT, the length of the cell cycle increases progressively as development continues and eventually expands into a typical somatic cell cycle in which all four phases of the cell cycle are represented. The precise manner in which new regulation is sequentially added to the embryonic cell cycle to generate a somatic cell cycle as development progresses is not well understood. The abrupt activation of changes in both cyclin A mRNA and protein stability that we have observed at the EGT suggest that equally important changes in cell cycle regulation might be occurring at this time. To address this possibility, we have used time lapse recording to carefully examine and analyze changes in cell division rates in developing embryos (Fig. 8).

During the cleavage stages (divisions 2-12), embryonic cells divided synchronously about every $22 \mathrm{~min}$. After the twelfth division, the embryo went through the MBT and blastomeres divided asynchronously with an expanded cell cycle. It is clear that there is a relatively modest increase in the length of the cell cycle immediately after the MBT. The duration of the thirteenth and

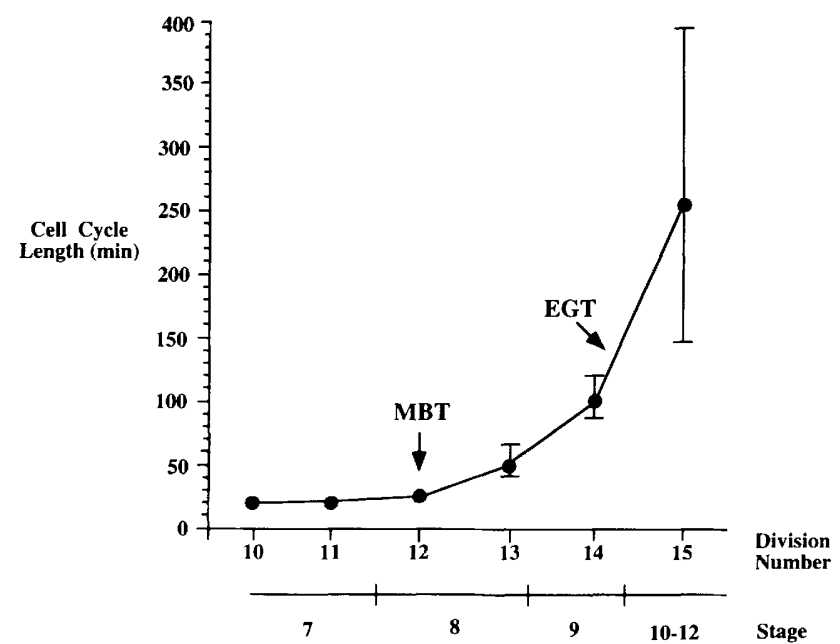

Figure 8. Expansion of the embryonic cell cycle after the twelfth cell division. A time lapse video recording of the animal cap of a single embryo was used. The average length of successive cell cycles for 7-well separated cells is plotted. Error bars indicate the range of cell cycle lengths measured at cleavage numbers 13,14, and 15 (divisions 10,11, and 12 occurred synchronously). Arrows indicate when the embryo went through the MBT and the approximate time of the EGT.

fourteenth cycles averaged 50 and $99 \mathrm{~min}$, respectively. However, after the EGT (cycle 15) the length of the cell cycle increased abruptly to $253 \mathrm{~min}(4.2 \mathrm{hr})$. This is on average 11 times longer than the cell cycles prior to the MBT. Therefore, the degradation of cyclin A $m R N A$ and activation of systems that cause cyclin A protein to turn over at the EGT correlate precisely with an abrupt and marked lengthening of the cell cycle. Although this correlation does not establish a causal relationship between these events, it is certainly consistent with such a possibility.

\section{Discussion}

Prior to the identification of cyclin A2, it was assumed that Xenopus cyclin Al was responsible for all of the cyclin A activity required during embryonic development and throughout the life of the organism. Our data suggest that cyclin $\mathrm{A} 2$ is a better candidate to fulfill the cyclin A requirement later in development. We find that cyclin A2 protein is present at very low levels in unfertilized eggs and during the cleavage stages. Following the $\mathrm{MBT}$, the level of cyclin A2 protein increases rapidly until it reaches a constant level throughout the neurula and later stages of development. In contrast, we observed that cyclin Al mRNA and protein are present in embryos until the beginning of gastrulation at which time they turn over rapidly. Both cyclin A1 and A2 mRNAs can be detected in testis, but we do not yet know whether they are expressed in the same or different cell types in this tissue. In mouse, a similar situation pertains, that is, two distinct cyclin A mRNAs have been identified. However, in this case, mouse cyclin Al (the 
somatic cyclin A) is found to be expressed in most adult tissues, whereas cyclin A2 is found primarily in the testis (M. Carrington, pers. comm.). As yet, we do not know whether we have accounted for all of the A-type cyclins in Xenopus; we have data to suggest that there may be a distinct A-type cyclin in skin (M. Howell, unpubl.).

\section{Regulation and possible functions of the A-type cyclins}

The prevailing dogma would suggest two possible functions for cyclin A throughout development: namely, a role in $S$ phase or a role in the $S-M$ transition. Evidence has accumulated to suggest that both cdk2 and cyclin $A$ play some role in DNA replication. The requirement for cdk2 has been demonstrated in Xenopus cell-free systems where removal of cdk2 inhibits the replication of DNA (Blow and Nurse 1990; Fang and Newport 1991). Antibody ablation and antisense RNA experiments in tissue culture cells have provided evidence that cyclin $\mathrm{A}$ is also required for S phase (Girard et al. 1991) and during $\mathrm{G}_{2}$ phase (Pagano et al. 1992). Moreover, cyclin A has been shown to colocalize with the sites of DNA replication in mouse cell lines, suggesting a direct role in the replication process (Cardosa et al. 1993). Although not formally demonstrated, it is presumed that the activity of cyclin A during $\mathrm{S}$ phase requires association with cdk2. There is some evidence to suggest that human cyclin $\mathrm{A}$ is predominantly complexed with cdk 2 in $\mathrm{S}$ phase, but complexed with cdc2 in $M$ phase (J. Pines, pers. comm.). It is unlikely that cyclin $\mathrm{A} 1$, or $\mathrm{A} 2$, is required during $\mathrm{S}$ phase of the cleavage cycles, as fertilized eggs, or egg extracts, that are treated with protein synthesis inhibitors efficiently replicate sperm DNA in the absence of cyclins A1, A2, B1, and B2 (Fang and Newport 1991). Moreover, we have found that only a fraction (if any) of cyclin Al protein complexes with cdk2 during cleavage (J. Howe and J. Newport, unpubl.), and while cyclin A2 does complex with cdk2 in later stage embryos (Fig. 3), the level of this complex in cleavage-stage embryos is very low. A better candidate for the cyclin partner of cdk2 that might fulfill the cdk2 requirement of replication in the earliest cleavage stages would be cyclin E1, which is relatively abundant in eggs and early embryos (as compared with cyclin A2) and binds exclusively to cdk2 (M. Howell and J. Howe, unpubl.). During the cleavage cycles, cyclin El is abundant and its levels do not oscillate significantly until immediately after the MBT when it becomes unstable and turns over rapidly (J. Howe and J. Newport, in prep.). After the MBT there is an increase in both the abundance of cyclin $A 2$ and in the level of cyclin A2-cdk2 complex (Figs. 4 and 5). Both observations might reflect an increasing role for cyclin A2-cdk2 complexes in replication during these later stages of development.

\section{Developmental regulation of cyclin $A 1$ and $A 2$ $m R N A$ and protein}

Following fertilization, the egg divides rapidly 12 times in $6 \mathrm{hr}$ to generate an embryo consisting of $\sim 4000$ cells at the MBT. Following the MBT, embryonic cells divide two to three more times during the $3 \mathrm{hr}$ preceding the onset of gastrulation. During these post-MBT cell divisions, the cell cycle lengthens progressively from $25 \mathrm{~min}$ at the MBT to $100 \mathrm{~min}$ at the beginning of gastrulation. Following the onset of gastrulation the cell cycle lengthens abruptly with a range of 3-6 hr. Although zygotic transcription in Xenopus is activated at the MBT, experimental evidence demonstrates that all 14-15 of the cell divisions preceding the onset of gastrulation occur normally in the absence of new zygotic transcription (Newport and Dasso 1989). This observation demonstrates that preceding the EGT, cell division is dependent only on maternal stores of mRNA and proteins. In this report we have shown that the maternal store of mRNAs encoding both cyclin A1 and A2 is stable prior to the EGT and then degraded rapidly. Thus, we have shown that cyclin A mRNA degradation occurs precisely at the time in development when further cell division becomes dependent on new zygotic transcription. The temporal coincidence between these two events suggests that cyclin A mRNA is one of the mRNAs that becomes limiting for cell division after the EGT, resulting in elongation of the cell cycle at this time in development.

With respect to the developmental regulation of cyclin proteins, we have shown that like cyclin A mRNAs, both cyclin $\mathrm{A} 1$ and $\mathrm{A} 2$ proteins appear to become very unstable in interphase of the cell cycle at the EGT. Our results also show that sudden turnover of cyclin A protein at the EGT is independent of the degradation of cyclin A proteins that normally occurs at each mitosis. Specifically, in S-phase-arrested embryos, cyclin A degrades at the equivalent of the EGT while cyclin B remains stable. This result, in combination with visual observation that nuclei remain intact in arrested embryos, demonstrates that the abrupt destabilization of cyclin $\mathrm{A}$ in these embryos is occurring during interphase of the cell cycle. Finally, although we find that cyclin A mRNAs and proteins become unstable at the same time, our results demonstrate that cyclin A protein degradation is not directly attributable to the degradation of cyclin A mRNA. In support of this, we have shown that in S-phase-arrested embryos treated with $\mathrm{CHX}$, cyclin A proteins are stable until the EGT and are then degraded abruptly.

Taken together, our results support the proposal that new degradative pathways are activated at the EGT which cause destabilization of both cyclin A mRNA and cyclin A proteins. As a result of the activation of these new degradative pathways, the concentration of these components during interphase of the cell cycle at the EGT will depend both on their rate of synthesis and rate of degradation. Thus, the activation of degradative pathways at the EGT adds a dynamic element to cyclin A1 and $\mathrm{A} 2$ protein regulation that is not present at interphase in cell cycles during the early embryonic cell cycle. Prior to the EGT, cyclin A protein accumulation appears to be controlled largely, if not exclusively, by translation of the stable pool of maternal cyclin A mRNA. However, following the EGT, interphase accu- 
mulation of cyclin A protein is regulated by three new variables: rate of cyclin A mRNA transcription, rate of cyclin A mRNA degradation, and rate of cyclin A protein degradation. Because cyclin A appears essential for both $S$ phase and mitosis, it is clear that the activation of these pathways provides several new potential mechanisms for cell cycle regulation.

\section{Developmental consequences of the EGT}

Prior to the EGT, the simple rapid embryonic cell cycle is controlled primarily by the repeated accumulation and degradation of cyclin protein during interphase and mitosis. As such, the cell cycle during this period is regulated by and dependent on the pool of maternal cyclin mRNAs that are synthesized and stored during oogenesis. Because new zygotic transcription does not occur until the MBT (Newport and Kirschner 1982b), it is essential that this accumulated pool of maternal mRNA remains stable during early development. In contrast, once zygotic transcription is activated, it is equally important that maternal mRNAs are degraded to eliminate maternal programs and allow newly transcribed messages to assume control of further cell division. With this in mind, it appears likely that the activation of cyclin A mRNA degradation at the EGT represents an essential developmental process that allows the simple early embryonic cell cycle driven by maternal mRNA to be replaced by a more complicated somatic cell cycle regulated by new zygotic transcription. Importantly, because new zygotic transcription within the eggs is a regulated event unique to the spatial localization of a cell within the embryo, the elimination of maternal information at the EGT represents the first time that cell division within the embryos will occur in a cell-autonomous and location-dependent manner. Therefore, the activation of cyclin A mRNA and protein turnover at the EGT are likely to represent a critical pathway that affects both cell cycle regulation and further embryonic development.

\section{A developmental timer controls activation of cyclin $A$ degradative pathways}

We can make several conclusions with respect to the timing mechanism that controls the onset of the cyclin A protein and mRNA degradative pathways at the EGT. First, the timing of the activation of these pathways does not appear to be tightly linked to the cell cycle. In support of this, we have found that when the cell cycle is arrested in S phase with $\mathrm{HU}$ or $\mathrm{CHX}$, cyclin A proteins and mRNA remain stable until the EGT and then are rapidly degraded. These experiments also indicate that the activation of these degradative pathways does not require zygotic transcription and proteins encoded by these new transcripts. Finally, we have shown that the timing mechanism regulating the activation of these degradative pathways is independent of new protein synthesis that occurs shortly after fertilization. This conclu- sion is based on the observation that eggs treated with CHX 1-2 hr after fertilization still degrade cyclin protein and mRNA at a time period equivalent to the EGT. Together, these results strongly suggest that the activation of the cyclin A mRNA and protein degradative pathways is regulated by a developmental timer that is itself activated at the time of fertilization. Although we do not know the molecular details of this developmental timer, at present, on the basis of the results presented here, we can propose that the timer does not rely on new transcription, new protein synthesis, number of cell cycles, or a specific nuclear to cytoplasmic ratio.

Overall our results indicate that degradation of cyclin A protein and mRNA is regulated by a developmentally autonomous timer that is activated at fertilization and goes off at the EGT. The EGT itself corresponds in time precisely with the onset of gastrulation. As such, the timer that controls the onset of cyclin A degradative pathways could be part of a timing mechanism contributing to the onset of gastrulation. The possibility of a "gastrulation timer" has been suggested by a number of experiments (for review, see Cooke and Smith 1990). In 1943, Holtfretter reported that activated unfertilized Rana pipien eggs underwent an extensive pigment rearrangement reminiscent of gastrulation at the time that fertilized control eggs began gastrulation. Because these activated eggs did not divide, this observation suggested that a timer acting independently of cell division, DNA replication, and transcription might participate in activating gastrulation movements. Further evidence in support of this proposal has been provided by Kobayakawa and Kubota (1981). These investigators showed that eggs divided into quarters prior to the first cleavage went through the MBT two cycles earlier than normal but initiated gastrulation at almost the same time as control embryos. This experiment supports the proposal that the MBT is controlled by the attainment of a critical nuclear to cytoplasmic ratio (Newport and Kirschner 1982b). However, it also suggests that the onset of gastrulation is independent of the timing of the MBT and may be regulated by a molecular mechanism that measures elapsed time by other methods. More recently, several investigators have demonstrated that specific landmark events associated with the onset of gastrulation are independent of cell division and protein synthesis after the MBT. For example, Gurdon and co-workers have shown that the loss of competence of ectodermal tissues to be induced to form mesoderm is independent of protein synthesis that occurs after the MBT (Grainger and Gurdon 1989). Taken together, these observations suggest that many of the essential events associated with the initiation of gastrulation may be coordinated and regulated by a developmental clock, which like the timer regulating cyclin A protein and mRNA degradation at the EGT, is activated at the time of fertilization and then measures time in a process that is independent of protein synthesis, mRNA synthesis, and cell cycle. Therefore, a detailed molecular characterization of the degradative mechanism responsible for cyclin A turnover at the EGT may provide important information about the developmental programs 
regulating the initiation of gastrulation during embryogenesis.

\section{Materials and methods}

Frogs, embryos, and egg extracts

Synchronous batches of developing embryos were obtained by in vitro fertilization using standard techniques (Newport and Kirschner 1982a). Embryos were maintained in either $0.1 \times$ modified Barth's solution or $0.25 \times$ modified Ringer's solution (Peng 1991) and staged according to Niewkoop and Faber (1967). Samples were flash frozen at the appropriate stages and kept at $-70^{\circ} \mathrm{C}$ until use. Where appropriate, $\mathrm{HU}(30 \mathrm{~mm}$ final concentration) or $\mathrm{CHX}(100 \mu \mathrm{g} / \mathrm{ml})$ was added to the culture medium without removal of the vitelline membrane. When CHX was used the embryos were incubated in Danilchik's solution (Peng 1991) without calcium to facilitate rapid uptake of this drug. Under these conditions, CHX has been shown to inhibit protein synthesis by $95 \%$ in embryos (S. Nichols and J. Newport, unpubl.). CSF-arrested egg extracts were made and used as described by Stewart et al. (1994).

\section{Cloning and sequencing of cyclin $A 2$}

Approximately $2 \times 10^{6}$ plaques of a Xenopus oocyte cDNA library la kind gift of Doug Melton, Harvard University, Cambridge, MA) in $\lambda$ gt 10 were plated out onto NZYM agar plates as described by Sambrook et al. (1989). Alkali-denatured nylon membranes with the lifted plaques were hybridized overnight at $65^{\circ} \mathrm{C}$ in $6 \times \mathrm{SSC}, 5 \times$ Denhardt's solution, $5 \mathrm{~mm}$ sodium phosphate, $2 \mathrm{~mm}$ sodium pyrophosphate, $0.1 \% \mathrm{SDS}$, and $10 \mu \mathrm{g} / \mathrm{ml}$ of salmon sperm DNA containing $2 \times 10^{5}$ to $5 \times 10^{5} \mathrm{cpm} / \mathrm{ml}$ of probe. The probe was a restriction fragment of the human cyclin A cDNA (a kind gift of $J$. Pines, Cambridge University, UK) corresponding to the cyclin box and carboxy-terminal region (a Bsu36I-EcoRI fragment) and was labeled by random priming in the presence of $\left[\alpha^{-32} \mathrm{P}\right] \mathrm{dCTP}$ (Megaprime, Amersham International). After $16 \mathrm{hr}$ of hybridization, filters were washed in $2 \times$ SSC, $0.1 \%$ SDS, at $65^{\circ} \mathrm{C}$ and exposed to film. After five rounds of plaque purification, 14 positives plaques that hybridized with the human probe but did not hybridize with a Xenopus cyclin A1 probe were analyzed further and essentially fell into two groups, the members within each differing only in the length of the insert. Sequence analysis of the clones with the largest inserts from each family revealed that they were novel cyclin A clones. The member of each group with the largest cDNA insert was sequenced completely by shotgun cloning into $\mathrm{M} 13 \mathrm{mp} 19$ and sequenced with dideoxy chain terminators and Sequenase (U.S. Biochemical) in the presence of $\alpha^{-{ }^{35}} \mathrm{~S}$-labeled dATP following the manufacturer's protocol. Each strand was sequenced 4 times in overlapping clones. The EcoRI insert from $\lambda$ plaques were subcloned into pGEMI (Promega) such that the T7 promoter synthesized sense mRNA. The extreme $5^{\prime}$ end sequence of cyclin A2 was obtained by PCR between an oligonucleotide directed against the amino terminus 15 '-CCACAGGGACGAGAAGCTTTCGGGGCTG-3') and one specific for the vector sequences flanking the EcoRI site of the $\lambda g t 10$ library used for the isolation of the initial clone. All PCR reactions were performed essentially as described by Mullis and Faloona (1987). The PCR fragment so obtained was subcloned between the EcoRI and SmaI sites of pGEM-1. Full-length cyclin A2 cDNA was reconstructed by digesting both the subcloned amino-terminal PCR fragment and the construct containing the full open reading frame with $X m n I$ and ligating one with the other.

\section{Antibodies}

Three cyclin A2-specific antisera were used in this study; a polyclonal rabbit serum raised against a MalE-cyclin A2 fusion protein, a monoclonal antibody against the same antigen and a polyclonal rabbit serum raised against an A2 peptide (MSDHLLRDEHQ). To construct the MalE-cyclin A2 fusion an EcoRI fragment containing the full-length open reading frame of cyclin A2 was subcloned into the EcoRI site of pMal-cRI (NEB) such that it was in-frame with the maltose binding protein (MBP). The insoluble MBP-cyclin A2 fusion protein was expressed in Escherichia coli TG1 cells according to manufacturers' recommendations and the insoluble fusion protein purified and electroeluted from acrylamide gels (Harlow and Lane 1988). Immunizations with this fusion were performed as described (Harlow and Lane 1988) using seven injections per animal. Monoclonal anti-cyclin A2 antibodies were made as described (Harlow and Lane 1988), with the mouse being boosted with 7.5 $\mu \mathrm{g}$ of soluble GST-A2 prior to sacrifice and isolation of the spleen. The anti-peptide A2 antibody was custom made using the services of Research Genetics (Huntsville, AL). Cyclin A1 (sheep anti-A1) and B2 (rabbit anti-B2) antibodies were raised against fusion proteins and were gifts of J. Maller (Boulder, $\mathrm{CO}$ ) and $M$. Kirschner (Harvard University, Cambridge, MA), respectively, polyclonal rabbit anti-Xenopus cyclin $\mathrm{Bl}$ and anti-cyclin Al antisera were a gift of J. Minshull (University of California at San Francisco). The cdc2 and cdk2 antibodies used have been described elsewhere (Fang and Newport 1991; Kobayashi et al. 1992).

\section{RNA analysis}

Total RNA from oocytes, eggs, and tissue culture cells was prepared as described (Chomczynski and Sacchi 1987; Sambrook et al. 1989). Total RNA prepared from sets of 15 frozen embryos was electrophoresed in formaldehyde-agarose gels and transferred either to nitrocellulose filters or nylon membrane ( $\mathrm{Hy}$ bond N, Amersham International) as described (Sambrook et al. 1989|. Ethidium bromide staining was used to check the integrity of the RNA. Filters were hybridized either according to the method of Church and Gilbert (1984) or in the presence of formamide as described by Sambrook et al. (1989) with full-length cyclin A1 or A2 cDNA probes. DNA fragments for probes were labeled with $\left[\alpha^{-}{ }^{32} \mathrm{P}\right] \mathrm{dCTP}(3000 \mathrm{Ci} / \mathrm{mmole}$ ICN, Irvine, CA or Amersham International) using a random primer-labeling system (GIBCO, Gaithersburg, MD, or Amersham International) according to the manufacturer's protocol. Northern blots were washed to high stringency at $65^{\circ} \mathrm{C}$ in $0.1 \times$ SSC, $0.1 \%$ SDS (Sambrook et al. 1989). For RNA preparations from adult tissues, the tissue was first ground to a fine powder under liquid nitrogen with a mortar and pestle. RNA was then isolated exactly as described (Chomczynski and Sacchi 1987). In vitro transcriptions were performed as described by Krieg and Melton (1987). In vitro translations using message-dependent rabbit reticulocyte lysates were performed as described by Jackson and Hunt (1983).

\section{Sample preparation for immunoprecipitation and SDS-PAGE}

Two different methods were used for the preparation of samples. Both methods gave qualitatively identical results.

Method 1 Extracts from frozen embryos were disrupted in mEB (20 mM HEPES, $80 \mathrm{~mm} \beta$-glycerol phosphate, $20 \mathrm{~mm}$ EGTA, $15 \mathrm{mM} \mathrm{MgCl}_{2}, 50 \mathrm{~mm} \mathrm{NaF}, 1 \mathrm{mM} \mathrm{NaVO}, 0.5 \mathrm{mM}$ PMSF, $0.5 \%$ NP-40 at $\mathrm{pH} 7.3$ ) by pipetting up and down at least 20 
times. After a 15-min incubation on ice, extracts were pipetted into $400 \mu \mathrm{l}$ microcentrifuge tubes (Beckman, Palo Alto, CA) and clarified by centrifugation in a microcentrifuge for $15 \mathrm{~min}$. Cytosol was collected and either stored on ice for further processing or treated with $4 \times$ sample buffer for SDS-PAGE. For immunopreciciptations and $\mathrm{p} 13^{\mathrm{sucl}}$ depletions, extracts from $20 \mathrm{em}$ bryos were diluted to $400 \mu \mathrm{l}$ with $\mathrm{mEB}$ and $20 \mu \mathrm{l}$ of $\mathrm{p} 13^{\text {Sucl }}$ Sepharose Beads (Dunphy and Newport 1989), or the appropriate antibodies and $30 \mu \mathrm{l}$ of a $50 \%$ slurry of protein A-Sepharose (Pharmacia, Piscataway, NJ), were added. Following a 1-hr incubation, the beads were rinsed 5 times with bead wash buffer $(50 \mathrm{~mm}$ Tris- $\mathrm{HCl}, 5 \mathrm{~mm} \mathrm{NaF}, 250 \mathrm{~mm} \mathrm{NaCl}, 5 \mathrm{~mm}$ EGTA, $5 \mathrm{~mm}$ EDTA, $0.5 \mathrm{~mm}$ PMSF, $0.1 \% \mathrm{NP}-40$ at $\mathrm{pH} 7.5$ ), or mEB, diluted in $30 \mu \mathrm{l}$ of $4 \times$ sample buffer, and boiled, and the supernatant was loaded on to $10 \%$ polyacrylamide-SDS gels.

Method 2 Immunoprecipitations and $\mathrm{p} 13^{\text {suc } 1}$ depletions from CSF-arrested egg extracts were performed as described (Stewart et al. 1994). Embryo and tissue culture cell extracts for immunoprecipitation and analysis by Western blotting were prepared by lysis in the presence of $1 \% \mathrm{NP}-40(20 \mathrm{~mm}$ Tris-Cl at $\mathrm{pH} 7.5$, $150 \mathrm{~mm} \mathrm{NaCl}, 20 \mathrm{~mm}$ EGTA, $20 \mathrm{~mm} \mathrm{NaF}, 1 \% \mathrm{NP}-40,0.5 \mathrm{~mm}$ $\mathrm{PMSF}$, and $10 \mu \mathrm{g} / \mathrm{ml}$ each of aprotinin, leupeptin, and chymostatin (Sigma)], using $5 \mu \mathrm{l}$ of buffer per embryo or $0.5 \mathrm{ml}$ of buffer per $140-\mathrm{mm}$ tissue culture dish $\left(1 \times 10^{7}\right.$ to $2 \times 10^{7}$ cells $)$. Embryos were homogenized by pipetting (for tissue culture cells, lysis was performed on the plates) and incubated on ice for $5 \mathrm{~min}$, and the homogenate was clarified by centrifugation at $14,000 \mathrm{rpm}$ for $5 \mathrm{~min}$. The protein concentration of the supernatant was estimated using the BioRad protein assay reagent and either made $1 \times$ in SDS sample buffer or used for immunoprecipitation. Antibody-antigen reactions were incubated on ice for $1 \mathrm{hr}$ and the complexes so formed collected on protein $\mathrm{A}$ beads (Affiprep protein A, Bio-Rad). Immunoprecipitates were washed three times with lysis buffer (or for tissue culture cells washes used high salt RIPA buffer $(80 \mathrm{~mm}$ sodium $\beta$-glycerophosphate ( $\mathrm{pH} 7.6$ ), $50 \mathrm{~mm} \mathrm{NaF}, 10 \mathrm{mM} \mathrm{Na} \mathrm{HPO}_{4}, 250 \mathrm{~mm}$ $\mathrm{NaCl}, 1 \mathrm{mM}$ EGTA, $1 \mathrm{mM}$ EDTA, $1 \% \mathrm{NP}-40$, and $0.1 \% \mathrm{SDS}$ ) and resuspended in $1 \times$ SDS sample buffer. Western blotting was carried out using standard techniques. Primary antibodies were detected by enhanced chemluminesence using an ECL kit (Amersham, Arlington Heights, IL).

\section{Acknowledgments}

We thank Julian Gannon, Jim Maller, and Marc Kirschner for their generous gifts of antibodies. The Xenopus oocyte cDNA library was a kind gift of Doug Melton, human cyclin A cDNA was a kind gift of Jon Pines, and WAK cells were a kind gift of Ron Laskey. We thank Gary Martin (ICRF) and Laurine Vanlerberg (University of California at San Diego) for maintaining the frogs and Ian Goldsmith at the ICRF oligonucleotide synthesis facility. We also thank Chris Hawkins, Mark Carrington, and Stuart Ravnik for sharing unpublished sequence information (pig cyclin A and mouse cyclin A1 and A2). Finally, we thank Jeff Stack for critically reading the manuscript and providing many useful suggestions. This work was supported by National Institutes of Health grant GM 33523-07 to J.N. and a fellowship from the Medical Research Council (Canada) to J.H.

The publication costs of this article were defrayed in part by payment of page charges. This article must therefore be hereby marked "advertisement" in accordance with 18 USC section 1734 solely to indicate this fact.

\section{Note}

The cyclin A2 sequence data have been deposited in the EMBL sequence data base under accession number X85746.

\section{References}

Bachvarova, R and E. Davidson 1966. Nuclear activation at the onset of amphibian gastrulation. J. Exp. Zool. 163: 285-296.

Baldin, V.J. Lukas, M.J. Marcote, M. Pagano, and G. Draetta. 1993. Cyclin D1 is a nuclear protein required for cell cycle progression in $\mathrm{G}_{1}$. Genes \& Dev. 7: 812-821.

Blow, J.J. and P. Nurse. 1990. A cdc2-like protein is involved in the initiation of DNA replication in Xenopus egg extracts. Cell 62: 855-862.

Cardosa, M.C., H. Leonhardt, and B. Nadal-Ginard. 1993. Reversal of terminal differentiation and control of DNA replication; cyclin A and cdk2 specifically localize at subnuclear sites of DNA replication. Cell 74: 979-992.

Chomczynski, P. and N. Sacchi. 1987. Single-step method of RNA isolation by acid guanidinium thiocyanate-phenolchloroform extraction. Anal. Biochem. 162: 156-159.

Church, G.M. and W. Gilbert 1984. Genomic sequencing. Proc. Natl. Acad. Sci. 81: 1991-1995.

Cooke, J. and J.C. Smith. 1990. Measurement of developmental time by cells of early embryos. Cell 60: 891-894.

Dasso, M. and J.W. Newport. 1990. Completion of DNA replication is monitored by a feedback system that controls the initiation of mitosis in vitro; studies in Xenopus. Cell 61: 811-823.

Desai, D., Y. Gu, and D.O. Morgan. 1992. Activation of human cyclin-dependent kinases in vitro. Mol. Biol. Cell 3: 571582.

Dulic, V., E. Lees, and S.I. Reed. 1992. Association of human cyclin $E$ with a periodic $G_{1}-S$ phase protein kinase. Science 257: 1958-1961.

Dunphy, W.G. and J.W. Newport. 1989. Fission yeast pl3 blocks mitotic activation and tyrosine dephosphorylation of the $X e$ nopus cdc2 protein kinase. Cell 58: 181-191.

Fang, F. and J.W. Newport. 1991. Evidence that the G1-S and G2-M transition are controlled by different cdc2 proteins in higher eukaryotes. Cell 66: 731-742.

Gabrielli, B.G., L.M. Roy, J. Gautier, M. Philippe, and J.L Maller. 1992. A cdc2-related kinase oscillates in the cell cycle independently of cyclin $\mathrm{G} 2 / \mathrm{M}$ and cdc2. J. Biol. Chem. 267: 1969-1975

Gautier, J., J. Minshull, M. Lohka, M. Glotzer, T. Hunt, and J.L. Maller. 1990. Cyclin is a component of maturation-promoting factor from Xenopus. Cell 60: 487-494.

Girard, F., U. Strausfeld, A. Fernandez, and N.J.C. Lamb. 1991. Cyclin $A$ is required for the onset of DNA replication in mammalian fibroblasts. Cell 67: 1169-1179.

Glotzer, M.A., A.W. Murray, and M.W. Kirschner. 1991. Cyclin is degraded by the ubiquitin pathway. Nature 349: 132-138.

Grainger, R.M. and J.B. Gurdon. 1989. Loss of competence in amphibian induction can take place in single nondividing cells. Proc. Natl. Acad. Sci. 86: 1900-1904.

Harlow, E. and D. Lane. 1988. Antibodies: A laboratory manual. Cold Spring Harbor Laboratory, Cold Spring Harbor, New York.

Hunt, T. 1991. Cyclins and their partners; from simple idea to complex reality. Semin. Cell Biol. 2: 213-222.

Jackson, R.J. and T. Hunt. 1983. Preparation and use of nuclease-treated rabbit reticulocyte lysates for the translation of eukaryotic messenger RNA. Methods Enzymol. 96: 50 74. 
Jeffreys, A.J., V. Wilson, D. Wood, and J.P. Simons. 1980. Linkage of adult $\alpha$ - and $\beta$-globin genes in $X$. laevis and gene duplication by tetraploidization. Cell 21: 555-564.

Kimelman, D., M. Kirschner, and T. Scherson. 1987. The events of the midblastula transition are regulated by changes in the cell cycle. Cell 48: 399-407.

Kobayakawa, Y. and H.Y. Kubota. 1981. Temporal pattern of cleavage and the onset of gastrulation in amphibian embryos developed from eggs with reduced cytoplasm. I. Embryol. Exp. Morphol. 62: 83-94.

Kobayashi, H.E. Stewart, R. Poon, J.P. Adamczewski, J. Gannon, and T. Hunt. 1992. Identification of the domains in cyclin A required for binding to, and activation of, p34 ${ }^{\mathrm{cdc} 2}$ and p32 $2^{\mathrm{cdk} 2}$ protein kianse subunits. Mol. Biol. Cell 3: 1279-1294.

Koff, A., F. Cross, A. Fisher, J. Schumacher, K. Leguellec, M. Philippe, and J.M. Roberts. 1991. Human cyclin E, a new cyclin that interacts with two members of the CDC2 gene family. Cell 66: 1217-1228.

Krieg, P.A. and D.A. Melton. 1987. In vitro RNA synthesis with SP6 RNA polymerase. Methods Enzymol. 155: 397-415.

Landstrom, U., H. Lovtrup-Rein, and S. Lovtrup. 1975. Control of cell division and cell differentiation by deoxynucleotides in the early embryo of Xenopus laevis. Cell Differ. 4: 313325.

Lew, D.J., V. Dulic, and S.I. Reed. 1991. Isolation of three novel human cyclins by rescue of $\mathrm{Gl}$ cyclin (Cln) function in yeast. Cell 66: 1197-1206.

Matsushime, H., M.F. Roussel, R.A. Ashmun, and C.J. Sherr. 1991. Colony-stimulating factor 1 regulates novel cyclins during the Gl phase of the cell cycle. Cell 65: 701-713.

Minshull, J., J.J. Blow, and T. Hunt. 1989. Translation of cyclin mRNA is necessary for extracts of activated eggs to enter mitosis. Cell 56: 947-956.

Minshull, J., R. Golsteyn, C.S. Hill, and T. Hunt. 1990. The Aand B-type cyclin associated cdc2-kinases in Xenopus turn on and off at different times in the cell cycle. EMBO I.. 9: $2865-2875$

Mullis, K.B. and F.A. Faloona. 1987. Specific synthesis of DNA in vitro via a polymerase-catalysed chain reaction. Methods Enzymol. 155: 335-350.

Murray, A.W. and M.W. Kirschner. 1989. Cyclin synthesis drives the early embryonic cell cycle. Nature 339: 275-280.

Newport, J.W. and M. Dasso. 1989. On the coupling between DNA replication and mitosis. I. Cell. Sci. (Suppl.) 12: 149160.

Newport, J. and M. Kirschner. 1982a. A major developmental transition in early Xenopus embryos: I. Characterization and timing of cellular changes at the midblastula stage. Cell 30: $675-686$.

Newport, J. and M. Kirschner. 1982b. A major developmental transition in early Xenopus embryos: II. Control of the onset of transcription. Cell 30: 687-696.

Newport, J. and M. Kirschner. 1984. Regulation of the cell cycle during Xenopus development. Cell 37: 731-742.

Nieuwkoop, P.D. and J. Faber. 1967. Normal table of Xenopus laevis (ed. Daudin), North-Holland Publishing, Amsterdam, The Netherlands.

Nurse, P. and Y. Bissett. 1981. Gene required in Gl for commitment to cell cycle and in G2 for control of mitosis in fission yeast. Nature 292: 558-560.

Nurse, P., P. Thuriaux, and K. Nasmyth. 1976. Genetic control of the cell division cycle in fission yeast Schizosaccharomyces pombe. Mol. \& Gen. Genet. 146: 167-178.

Ohtsubo, M. and J.M. Roberts. 1993. Cyclin-dependent regulation of $G_{1}$ in mammalian fibroblasts. Science 259: 19081911.
Pagano, M., R. Pepperkok, F. Verde, W. Ansorge, and G. Draetta. 1992. Cyclin A is required at two points in the human cell cycle. EMBO J. 11: 961-971.

Paris, J., R. Le Guellec, A. Couturier, K. Le Guellec, F. Omilli, J. Camonis, S. MacNeill, and M. Philippe. 1991. Cloning by differential screening of a Xenopus cDNA coding for a protein highly homologous to cdc2. Proc. Natl. Acad. Sci. 88: 1039-1043.

Peng, H.B. 1991. Appendix A. Methods Cell Biol. 36: 657-662.

Pines, J. and T. Hunter. 1991. Human cyclins A and B1 are differentially located in the cell and undergo cell cycle depedent nuclear transport. I. Cell Biol. 115: 1-17.

Prioleau, M.-N., J. Huet, A. Sentenac, and M. Mechali. 1994. Competition between chromatin and transcription complex assembly regulates gene expression during early development. Cell 77: 439-449.

Reed, S.I. and C. Wittenburg. 1990. A mitotic role for the Cdc28 protein kinase of S. cerevisiae. Proc. Natl. Acad. Sci. 87: 5697-5701.

Sambrook, J., E.F. Fritsch, and T. Maniatis. 1989. Molecular cloning: A laboratory manual, 2nd ed., Cold Spring Harbor Laboratory Press, Cold Spring Harbor, New York.

Sherr, C.J. 1993. Mammalian $\mathrm{G}_{1}$ cyclins. Cell 73: 1059-1065.

Solomon, M.J., T. Lee, and M.W. Kirschner. 1992. Role of phosphorylation in $\mathrm{p} 34^{\text {cdc2 }}$ activation; identification of an activating kinase. Mol. Biol. Cell 3: 13-27.

Stewart, E., H. Kobayashi, D. Harrison, and T. Hunt. 1994. Destruction of Xenopus cyclins A and B2, but not B1 requires binding to p34 ${ }^{\text {cdc2 }}$. EMBO I. 13: 584-594.

Tsai, L.-H., E. Harlow, and M. Meyerson. 1991. Isolation of the human cdk2 gene that encodes the cyclin A- and adenovirus E1A-associated p33 kinase. Nature 353: 174-177.

Westley, B., T. Wyler, G. Ryffel, and R. Weber. 1981. Xenopus laevis serum albumins are encoded in two closely related genes. Nucleic Acids Res. 9: 3557-3574.

Xiong, Y., T. Connolly, B. Futcher, and D. Beach. 1991. Human D-type cyclin. Cell 65: 691-699. 


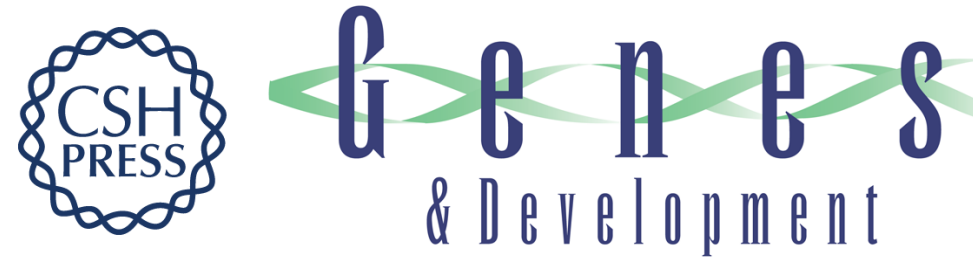

\section{Identification of a developmental timer regulating the stability of embryonic cyclin A and a new somatic A-type cyclin at gastrulation.}

J A Howe, M Howell, T Hunt, et al.

Genes Dev. 1995, 9:

Access the most recent version at doi:10.1101/gad.9.10.1164

References This article cites 51 articles, 12 of which can be accessed free at:

http://genesdev.cshlp.org/content/9/10/1164.full.html\#ref-list-1

License

Email Alerting

Service

Receive free email alerts when new articles cite this article - sign up in the box at the top right corner of the article or click here.

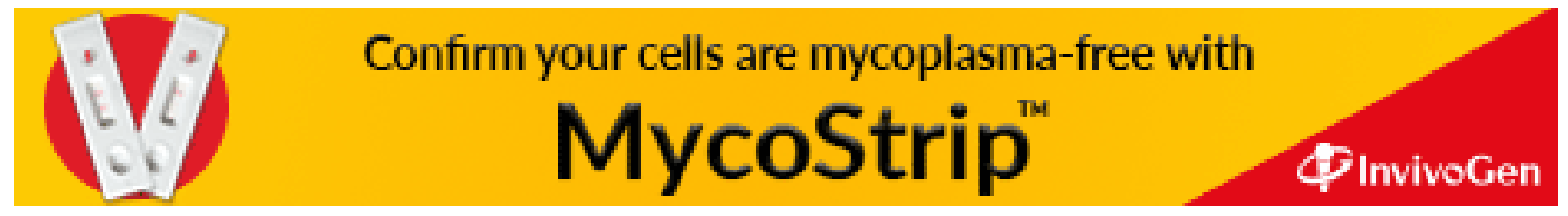

